\title{
Assessing urban recreation ecosystem services through the use of geocache visitation and preference data: a case-study from an urbanised island environment
}

\author{
Mario V Balzan $¥$, lain Debono $¥$ \\ ‡ Institute of Applied Sciences, Malta College of Arts, Science and Technology, Paola, Malta
}

\author{
Corresponding author: Mario V Balzan (mario.balzan@mcast.edu.mt) \\ Academic editor: Davide Geneletti \\ Received: 15 Feb 2018 | Accepted: 31 May 2018 | Published: 05 Jun 2018 \\ Citation: Balzan MV, Debono I (2018) Assessing urban recreation ecosystem services through the use of \\ geocache visitation and preference data: a case-study from an urbanised island environment. One Ecosystem 3 : \\ e24490. https://doi.org/10.3897/oneeco.3.e24490
}

\begin{abstract}
Recreation is an important cultural ecosystem service and is one way in which communities experience the direct and indirect benefits arising from the experiential use of their environment. The recent rise in popularity of Global Positioning System (GPS) game applications, which combine information technology with an activity that increases mobility and encourages outdoor enjoyment, provides ecosystem service practitioners with an opportunity to make use of this georeferenced data to assess recreational ecosystem services. Geocaching is one such worldwide outdoor game. It has fixed points of incursion where people can hide and look for caches. This study explores the possibility of using geocaching data as a proxy for recreational ecosystems services in the Maltese Islands. A quantitative analysis of the georeferenced caches was used together with their visit rates and number of favourite points. This was supplemented by two questionnaires that investigated the preferences and experiences of both geocache placers $(n=39)$ and hunters $(n=21)$. Results show that the highest number of caches were placed and searched for in urban areas and that geocaching is strongly associated with the presence and accessibility of urban green infrastructure. The number of geocachers who stated preference for
\end{abstract}


experiences in nature did not translate into high visit rates to sites of high conservation value (protected areas) but landscape value was significantly associated with recreational ecosystem services flow. The results presented here provide evidence that geocaching spatial data can act as an indicator for assessing and mapping recreational ecosystem services in urban environments and in cultural landscapes.

\section{Keywords}

Cultural Ecosystem Services; Ecosystem Service Capacity; Ecosystem Service Flow; Global Positioning System; Green Infrastructure; Urban Ecosystem Service

\section{Introduction}

The assessment and mapping of ecosystems and their services is a commitment of the European Union (EU) member states under Action 5 of the EU Biodiversity Strategy to 2020. Activities carried out under this commitment should support the maintenance and restoration of ecosystems and their services in order to ensure human well-being. This statement is supported by recent work at pan-European scale, which has shown that ecosystems in favourable conditions support biodiversity and have a higher capacity to supply ecosystem services and, in particular, regulating and cultural services, in comparison to habitats in unfavourable conditions (Maes et al. 2012). However, the integration of ecosystem services in landscape planning and management still presents a number of challenges, which amongst others are associated with our understanding of biodiversity - ecosystem service relationships, the identification of methods and tools that can be used to quantify, map and value ecosystem services, whilst taking into account variation across spatio-temporal scales and the arising trade-offs from land use and land cover changes (de Groot et al. 2010). Driven by policy questions and different governance contexts, various conceptual frameworks have been developed for the assessment and mapping of ecosystem services (de Groot et al. 2010, Maes et al. 2016b, Müller and Burkhard 2012, Potschin and Haines-Young 2011). Indicators are often used to derive information that communicates the characteristics and trends of ecosystem services, hence making it possible for policy-makers to understand their condition, trends and rate of change (Maes et al. 2016a).

Cultural ecosystem services are defined in the Common International Classification of Ecosystem Services (CICES) as all the non-material and normally non-consumptive, ecosystem outputs that affect physical and mental states of people (Haines-Young and Potschin 2013). Examples of cultural ecosystem services include the appreciation of landscape aesthetics, tourism and recreation, symbolic values of species and ecosystems and the educational, scientific, spiritual and religious value (de Groot et al. 2010, HainesYoung and Potschin 2013, M.A. 2005). Recreation services are an important subset of cultural services, which are often associated with aesthetics and symbolic values of ecosystems (Weyland and Laterra 2014, Balzan et al. 2018, Daniel et al. 2012). Outdoor 
recreation is important for millions of people and is a service that is dependent on the availability, distribution and type of ecosystems (Koniak et al. 2012, Maes et al. 2016b, Paracchini et al. 2014).

The recent phenomenon of social media and the availability of tools to geotag recreational activities has created a number of possibilities to use such data to analyse the benefits and values derived from cultural ecosystem services. Amongst others, several recent studies have assessed site visitation for recreation and tourism using geotagged photos and site visitation records such as from Flickr*1, Instagram² and Twitter*3 (Figueroa-Alfaro and Tang 2016, Hausmann et al. 2017, Richards and Friess 2015, Tenkanen et al. 2017). Similar to these social media, the Geocaching*4 worldwide outdoor game presents an opportunity to obtain spatially-explicit data about the use of ecosystems for recreation (Cord et al. 2015). Global Positioning System (GPS) based game applications are becoming increasingly popular as they combine information technology with an activity that increases mobility and outdoor enjoyment as they require human incursion into different areas and habitats.

Geocaching is an example of a GPS-based outdoor game. It has been available since the year 2000 and is today described on its website as the world's largest treasure hunt. Geocaching has fixed incursion sites spread over a variety of terrestrial and coastal ecosystems. It has more than 3 million active geocaches in 191 different countries across the 7 continents, more than 360,000 geocache owners and 585 million "Found it" and "Event Attended" logs have been recorded since the game started 5 . Geocachers hide a geocache and then record the GPS coordinates of that location along with a description of the cache on to a game website. The geocaching community can then look for the geocache and record the find on the same page, together with notes on the state of the cache, difficulty and other comments and photos. This form of communication is vital to help maintain individual caches and, collectively, the entire geocaching activity (Neustaedter et al. 2010). Geocaching can be described as a form of recreation carried out in settings created by natural ecosystems but can also be experienced in urban green spaces. In addition, as opposed to traditional approaches that assess the capacity of ecosystems to provide recreational ecosystem service using spatial data on the size, quality and accessibility of green spaces, geocaching data comprise georeferenced localities of geocaches and their visit rates, which can be used as a direct measure of the actual flow of recreational ecosystem services (Cord et al. 2015). Previous research from Germany about the preferences of geocachers indicates that the environment of the geocache location is an important characteristic determining the attractiveness of the geocache whilst the main motivation of geocachers was the possibility to be in nature, to familiarise oneself with the environment and for recreational purposes (Telaar et al. 2014).

This national case-study assesses the use of Geocaching data to assess recreational ecosystem service delivery in the small island state of Malta. More specifically, the objectives of the study are to assess:

1. the influence of the ecosystem type, distribution and accessibility on recreational ecosystem services delivery and 
2. on the actual use (flow) of this ecosystem service measured using both geocache visitation data and questionnaires with geocachers that allow for a better understanding of their motivation for determining ecosystem service flow.

\section{Material and methods}

\section{Conceptual approach}

In order to implement the concept of ecosystem services, various frameworks distinguish between the different components of ecosystem delivery (Bastian et al. 2013, Potschin and Haines-Young 2011, Villamagna et al. 2013). We distinguish between the ecosystem service capacity and flow based on the definitions in Villamagna et al. (2013). The ecosystem service capacity is defined as the maximum potential of ecosystems to deliver an ecosystem service based on the biophysical and social characteristics. The capacity of cultural ecosystem services may be more difficult to quantify, in comparison to provisioning and regulatory ecosystem services, as it varies across the landscape as a function of the range of biophysical (including land use and cover, climate, habitat and topography) and social (e.g. site management and accessibility) features (Villamagna et al. 2014, Villamagna et al. 2013). The ecosystem service flow is defined as the actual use of the service, which can be measured directly as the amount of a services delivered or indirectly as the number of beneficiaries served. The ecosystem service flow is different from the ecosystem service demand as the latter is a measure of the amount of ecosystem service required or desired by society and, for cultural ecosystem services, may include measures of the number of people wanting to experience that service (Villamagna et al. 2013).

Within this study, we use geocaching data as a proxy for recreational ecosystem services in a multifunctional landscape (Table 1). The distinction between the capacity and flow is particularly useful given that availability of different forms of geocaching data (Cord et al. 2015) and, namely, information about the availability of geocaches within landscapes as a measure of the ecosystem service capacity and the actual ecosystem service flow measures as the number of quests and number of favourite points. Through a spatial analysis, this study assesses the influence of the different site characteristics, such as the predominant land use, accessibility and landscape aesthetic value, on the capacity of ecosystems to provide recreational ecosystem services measured through geocache point data. Similarly, an analysis of the factors impacting on ecosystem service flow (i.e. how much is delivered) is also carried out. In addition, similar to Cord et al. (2015) and following on the approach in this study, we have used an adapted questionnaire with local geocachers in order to obtain further information on the choices of geocachers and to assess the degree of attraction for different geocache environmental characteristics. 
Table 1.

Explanation of geocaching terms (based on descriptions in http://www.geocaching.com and Cord et al. 2015).

\begin{tabular}{|c|c|}
\hline Term & Explanation \\
\hline Quest & Total number of people who either found or did not find the cache. \\
\hline $\begin{array}{l}\text { Favourite } \\
\text { points }\end{array}$ & $\begin{array}{l}\text { For every ten geocaches that a cacher with a premium account has found, he/she will be able to } \\
\text { identify his/her favourite in one exceptional geocache in his/her find history. }\end{array}$ \\
\hline $\begin{array}{l}\text { Geocache } \\
\text { hunter }\end{array}$ & Geocaching user who has logged caches within the study area. \\
\hline $\begin{array}{l}\text { Geocache } \\
\text { placer }\end{array}$ & $\begin{array}{l}\text { Geocache owners who placed their geocache within the study area and who retains all } \\
\text { responsibility for geocache listing and care. }\end{array}$ \\
\hline $\begin{array}{l}\text { Traditional } \\
\text { Geocache }\end{array}$ & $\begin{array}{l}\text { This is the original type of geocache consisting of a container at the given coordinates. As a } \\
\text { minimum, all of the geocaches will have a logbook. }\end{array}$ \\
\hline $\begin{array}{l}\text { Mystery } \\
\text { cache }\end{array}$ & $\begin{array}{l}\text { This type of geocache may involve complicated puzzles that one will first need to solve to determine } \\
\text { the correct coordinates. }\end{array}$ \\
\hline Multi-cache & $\begin{array}{l}\text { These geocaches involve two or more locations, with the final location being a physical container } \\
\text { with a logbook inside. At the first stage, the geocache hunter will receive a clue to the whereabouts } \\
\text { of the second stage. The second stage will have a clue for the third and so on. }\end{array}$ \\
\hline EarthCache & $\begin{array}{l}\text { An EarthCache is a special geological location people can visit to learn about a unique feature of } \\
\text { the Earth. EarthCache pages include a set of educational notes along with coordinates. }\end{array}$ \\
\hline $\begin{array}{l}\text { Letterbox } \\
\text { Hybrid }\end{array}$ & $\begin{array}{l}\text { Letterboxing is another form of treasure hunting that uses clues instead of coordinates. These types } \\
\text { of geocaches will contain a stamp that is meant to remain in the box and is used by letterboxers to } \\
\text { record their visit. }\end{array}$ \\
\hline $\begin{array}{l}\text { Wherigo }{ }^{\mathrm{TM}} \\
\text { Cache }\end{array}$ & $\begin{array}{l}\text { Wherigo is a toolset for creating and playing GPS-enabled adventures in the real world. By } \\
\text { integrating a Wherigo experience, called a cartridge, with finding a geocache, the geocaching hunt } \\
\text { can be an even richer experience. Amongst other uses, Wherigo allows geocachers to interact with } \\
\text { physical and virtual elements such as objects or characters while still finding a physical geocache } \\
\text { container. }\end{array}$ \\
\hline
\end{tabular}

Within this study, we have adapted the methodology used by Cord et al. (2015) to the multifunctional landscapes of the study area (Balzan et al. 2018). In a multifunctional landscape perspective, ecosystems serve more than one purpose, are considered in terms of their interactivity and their role in leading to improved well-being in different ways. Multifunctional landscapes can be thought of as a heterogeneous matrix that results from tangible interactions between natural and cultural systems (O'Farrell and Anderson 2010, Selman 2009). Within this study, we have therefore considered all geocaches, matching the inclusion criteria identified in this study and considered different types of caches across the cultural landscapes of the study area independent of the LULC category. Previous research has shown that the attraction of the cache tends to be very strongly associated with the attractiveness of the landscape (Telaar et al. 2014), suggesting the importance of an analysis that considers the entire landscape matrix (sensu Selman 2009). Hence, we consider all geocaches within Maltese Islands in order to obtain a measure of the (natural and social) features of the landscape that permit the delivery of this service. 


\section{Study Area}

The island state of Malta is situated in the Central Mediterranean Sea at $96 \mathrm{~km}$ south of Sicily and almost $300 \mathrm{~km}$ east of Tunisia. With a surface area of around $316 \mathrm{~km}^{2}$, the archipelago consists of three inhabited islands (Malta, Gozo and Comino) and several uninhabited islets. The first evidence of human settlement in Malta dates back to around 7000 BP (Patton 1996) and the landscapes of the Islands have been moulded over millennia by human exploitation, resource use and the geoclimatic conditionswhich harbour considerable biodiversity (Schembri 1997). Today agricultural land cover occupies around $51 \%$ of the territory, whilst built-up, industrial and urban areas occupy more than $30 \%$ of the Maltese Islands (M.E.P.A. 2010). Malta has a population density of 1,346 persons per $\mathrm{km}^{2}$ (N.S.O. 2014), the highest in the European Union and a growing tourism industry which, in 2016, surpassed 1.6 million tourists (N.S.O. 2017).

Recent research within the area of study has indicated the important role of ecosystems for the delivery of the key ecosystem services and that semi-natural and agricultural habitats are associated with a high ecosystem service capacity within this island environment. However, the actual use of ecosystem services (flow) was higher in small green urban and peri-urban areas. Coastal habitats were associated with cultural ecosystem services, in the form of habitats of conservation value (ecosystem service capacity) and aesthetic value (ecosystem service flow), but green urban areas and urban environments were also identified by survey respondents as having a high aesthetic value and for the provision of recreational ecosystem services (Balzan et al. 2018).

\section{Data Collection}

\section{Spatial analysis of ecosystem service capacity and flow}

Data for geocaching activities in Malta were obtained from the Groundspeak, Inc. Geocaching platform on 14 February 2017. For this study, we focused on caches which had been placed for more than 100 days and that have accessible geographic coordinates. We obtained information on the name, location (latitude/longitude), geocache type, date of placement, number of favourite points and number of quests. This information provided us with quantitative data on the availability (ES capacity) and the actual use (ES flow) of ecosystems through this recreational outdoor activity. The average number of quests and favourites per year in each geocache location was then calculated.

Information about the land use and cover of each geocache was obtained from a land use land cover (LULC) map that consists of 13 LULC categories (Balzan et al. 2018). The LULC map was developed through the use of Sentinel 2 satellite images acquired on 21-08-2016 by the Copernicus land monitoring system and which has a spatial resolution of up to $10 \mathrm{~m}$ (Drusch et al. 2012). In order to distinguish between different urban land uses, we used the European Urban Atlas as reference data (Urban Atlas, European Environmental Agency (EEA), 2012) which is based on earth observation data with $2.5 \mathrm{~m}$ spatial resolution and a minimum mapping unit of 0.25 ha. The Urban Atlas land use categories were reclassified 
into 11 coarser land use categories in order to increase the statistical power of the analysis. Additionally, in order to assess the potential role of different land uses on recreational ecosystem service delivery, geocache point data were overlaid with spatial data for the different types of designated protected areas for the Maltese Islands, obtained in March 2017 (Common Database on Designated Areas; CDDA, 2017). The CDDA holds information about protected sites under national and international legislation that directly or indirectly create protected areas and has similarly been used in previous literature assessing recreational ecosystem services in Europe (Paracchini et al. 2014). In addition, the proximity to residential areas within the study area, including the road (Geofabric, 2017) and (day) public transport network (downloaded from the Malta Public Transport website in June 2017) and the coastal environment (European Commission Inspire Directive Geoportal), was calculated as the minimum distance from these vector data.

\section{Understanding geocacher motivations determining ecosystem service flow}

In order to obtain information on the preferences of geocachers, two sets of questionnaires, one for the geocache hunters (Appendix 1, Suppl. material 1) and another questionnaire for the geocache placers (Appendix 2, Suppl. material 1), were administered with the geocaching community within the study area. The participants in this study were Geocachers in the Maltese Islands and the questionnaires were shared with members of the Geocaching Malta Facebook group ${ }^{\star} 6$, the Geocaching application itself and were also physically distributed with geocachers in person. Those who did not respond to the questionnaire within the set time of 4 weeks were then sent a reminder over a 10-month period. All potential contacts were approached to participate to maximise responders. Duplicate responses were excluded from the study, as were responses submitted by members of the geocaching community who did not reside within the study area.

\section{Data Analysis}

The influence of land cover and geocache type on the number of quests and favourite points was assessed through the use of a generalised linear model (GLM) with a negative binomial distribution due to the overdispersion of the count geocache data. The time since the placement of the geocache was included as an offset vector in order to account for different levels of visitation arising from the variation in time since the geocache was set up (Venables and Ripley 2002) (Appendix 3, Suppl. material 1). Subsequently, generalised linear mixed models (GLMM), with a negative binomial distributon, were used in order to assess the influence of categorical and continuous fixed variables on the number of quests and favourite points, whilst keeping geocache type as a random variable (Fournier et al. 2012, Skaug et al. 2013). Given the influence of urban land cover on the quest and favourite points data (Results), the GLMM for protected areas, including both the geocache type and the intersecting land use land cover of the geocache,were included as a random variable. The structure of the random variable for the model with the lowest AICc value was selected. The significance of the fixed variables was tested through elimination of the least significant effects or interaction, using likelihood ratio tests in which deviance with and without the term in the models were compared using a $x^{2}$ test. 
All spatial operations and statistical analysis were carried out using $R$ language and environment for statistical computing (R Development Team 2016), whilst QGIS 2.18 Las Palmas geographic information system was used in order to visualise spatial data (QGIS Development Team 2016).

\section{Results}

\section{Spatial analysis of ecosystem service capacity and flow}

A total of 318 geocaches from the study area were investigated in this study (Fig. 1). The geocaches were distributed in five cache type categories, with traditional caches $(n=231)$ and mystery caches (50) being the most common geocache types (Fig. 2a). Most of the caches were located in the urban LULC category ( $n=111$, Fig. 2b). Geocache type and LULC category were significantly associated with the number of quests and favourite points but no significant interactions between these two categorical factors were recorded. Urban caches were associated with a significantly higher number of quests in comparison to marine and other terrestrial LULC categories (Table 2), while marine caches had a significantly higher number of favourite points when compared to urban areas. When using the reclassified urban atlas land use spatial data, the geocaches were distributed amongst agricultural and semi-natural areas (168), roads (41), industrial (34), marine (22), urban high density (15), urban low density (13), urban green, sport and leisure areas (11) and other (12). The highest cache density was recorded in woodland areas, but the number of caches in this category was low, followed by orchards and shrub communities, sparsely vegetated land and grassland land cover (Fig. 3a). The EEA Urban Atlas land use categories were used to provide a clearer indication of the type of urban land uses of geocaches. Urban green and sports and leisure areas had the highest geocache density, after forests which accounted for only one geocache and a small fraction of the study area (Fig. 3b). The number of quests and favourite points also differed between different land use categories (Fig. 4). The type of urban and industrial land use had a significant impact on the number of quests and favourite points (Table 3). Geocaches in urban low density and agricultural land uses and the marine environment had a lower number of quests. Weaker associations were generally recorded from the GLMM for the number of favourite points but geocaches in green urban, sports and leisure areas and the marine environment had the highest rating while mines and construction sites were associated with the lowest number of favourite points. 
Table 2 .

Parameter estimates using GLM with a negative binomial distribution for the number of quests and favourite points when compared to the Urban LULC are shown. The most parsimonious model (lowest Akaike Information Criterion with a second order correction, AICc) for each response variable was selected as the best model. ${ }^{\star} 0.01<P<0.05,{ }^{* \star} 0.001<P<0.01,{ }^{* \star *} \mathrm{P}<0.001 ; \mathrm{P}$ values obtained from Wald test statistic $(Z)$ for each parameter.

\begin{tabular}{|c|c|c|c|c|}
\hline & \multicolumn{2}{|c|}{ Number of Quests } & \multicolumn{2}{|c|}{ Favourite points } \\
\hline & Est $( \pm S E)$ & Z & Est $( \pm \mathrm{SE})$ & Z \\
\hline Intercept & $4.88(0.21)$ & $23.62^{\star \star \star}$ & $2.51(0.29)$ & $8.66^{\star \star \star}$ \\
\hline Marine & $-0.60(0.16)$ & $-3.66^{\star * \star}$ & $0.58(0.23)$ & $2.47^{\star}$ \\
\hline Arable & $-0.69(0.12)$ & $-5.75^{\star \star \star}$ & $-0.28(0.17)$ & -1.61 \\
\hline Garrigue & $-0.66(0.19)$ & $-3.44^{\star * \star}$ & $-0.001(0.28)$ & -0.002 \\
\hline Grassland & $-0.87(0.14)$ & $-6.10^{\star \star \star}$ & $-0.04(0.20)$ & -0.19 \\
\hline Orchard & $-0.57(0.14)$ & $-4.03^{\star \star \star \star}$ & $-0.60(0.21)$ & $-2.88^{\star *}$ \\
\hline Sparsely vegetated land & $-0.30(0.18)$ & -1.63 & $0.14(0.26)$ & 0.55 \\
\hline Woodland & $-0.70(0.34)$ & $-2.04^{*}$ & $0.39(0.49)$ & 0.81 \\
\hline Letterbox Hybrid & $0.08(0.48)$ & 0.17 & $0.06(0.67)$ & 0.083 \\
\hline Multi-cache & $-0.39(0.27)$ & -1.47 & $-0.28(0.38)$ & -0.76 \\
\hline Traditional Cache & $0.17(0.21)$ & 0.80 & $-1.14(0.29)$ & $-3.88^{\star \star \star}$ \\
\hline Mystery cache & $-0.73(0.23)$ & $-3.24^{\star *}$ & $-0.83(0.32)$ & $-2.60^{\star \star}$ \\
\hline Wherigo cache & $-1.89(0.78)$ & -2.44 & $-0.66(1.08)$ & -0.61 \\
\hline df & \multicolumn{2}{|l|}{289} & \multicolumn{2}{|l|}{289} \\
\hline $\mathrm{AlCc}$ & \multicolumn{2}{|l|}{4171.08} & \multicolumn{2}{|l|}{2373.13} \\
\hline$\triangle \mathrm{AICc}$ & \multicolumn{2}{|l|}{22.56} & \multicolumn{2}{|l|}{7.86} \\
\hline
\end{tabular}

Table 3 .

Association of the geocaching number of quests and favourite points from the study area with the reclassified Urban Atlas categories, obtained from GLMM with a negative binomial error distribution and using the number of years from geocache placement as an offset in the analysis and geocache type as a random variable. Estimated parameters (Est) and Wald test values (Z) from the GLMM, when compared to the Urban - High Density category, are shown. ${ }^{\$} 0.05<P<0.1,{ }^{*} 0.01<P<0.05$, ${ }^{* *} 0.001<\mathrm{P}<0.01,{ }^{* *} \mathrm{P}<0.001 ; \mathrm{P}$ values obtained from Wald $z$-statistics for each parameter.

\begin{tabular}{|l|l|l|l|l|}
\hline \multicolumn{2}{|l}{ Number of Quests } & \multicolumn{3}{l|}{ Favourite points } \\
\hline & Est $( \pm$ SE) & $Z$ & Est $( \pm$ SE) & Z \\
\hline Intercept & $\mathbf{4 . 7 4 ( 0 . 2 7 )}$ & $\mathbf{1 7 . 5 7 ^ { * * * }}$ & $\mathbf{1 . 9 1 ( 0 . 3 9 )}$ & $\mathbf{4 . 9 1}^{* * *}$ \\
\hline Urban - Low Density & $-0.59(\mathbf{0 . 2 8})$ & $-2.07^{*}$ & $-0.08(0.43)$ & -0.19 \\
\hline Industrial & $0.10(0.23)$ & 0.68 & $0.34(0.35)$ & 0.97 \\
\hline Roads & $-0.40(0.23)$ & $-1.78^{\$}$ & $-0.41(0.34)$ & -1.20 \\
\hline
\end{tabular}




\begin{tabular}{|l|l|l|l|l|}
\hline Airport and ports & $-0.54(0.39)$ & -1.39 & $-0.33(0.57)$ & -0.58 \\
\hline Mines and construction & $-0.13(0.47)$ & -0.28 & $-1.61(0.82)$ & $-1.94^{\$}$ \\
\hline Green urban \& leisure areas & $0.05(0.28)$ & 0.18 & $0.82(0.42)$ & $1.96^{\$}$ \\
\hline Agriculture & $-0.81(0.20)$ & $-4.00^{* \star \star}$ & $0.089(0.31)$ & 0.29 \\
\hline Forests & $-0.63(0.79)$ & -0.81 & $-0.76(1.15)$ & -0.66 \\
\hline Water & $-0.69(0.47)$ & -1.47 & $-0.16(0.69)$ & -0.23 \\
\hline Marine & $-0.66(0.25)$ & $-2.63^{* \star *}$ & $0.50(0.37)$ & 1.35 \\
\hline
\end{tabular}

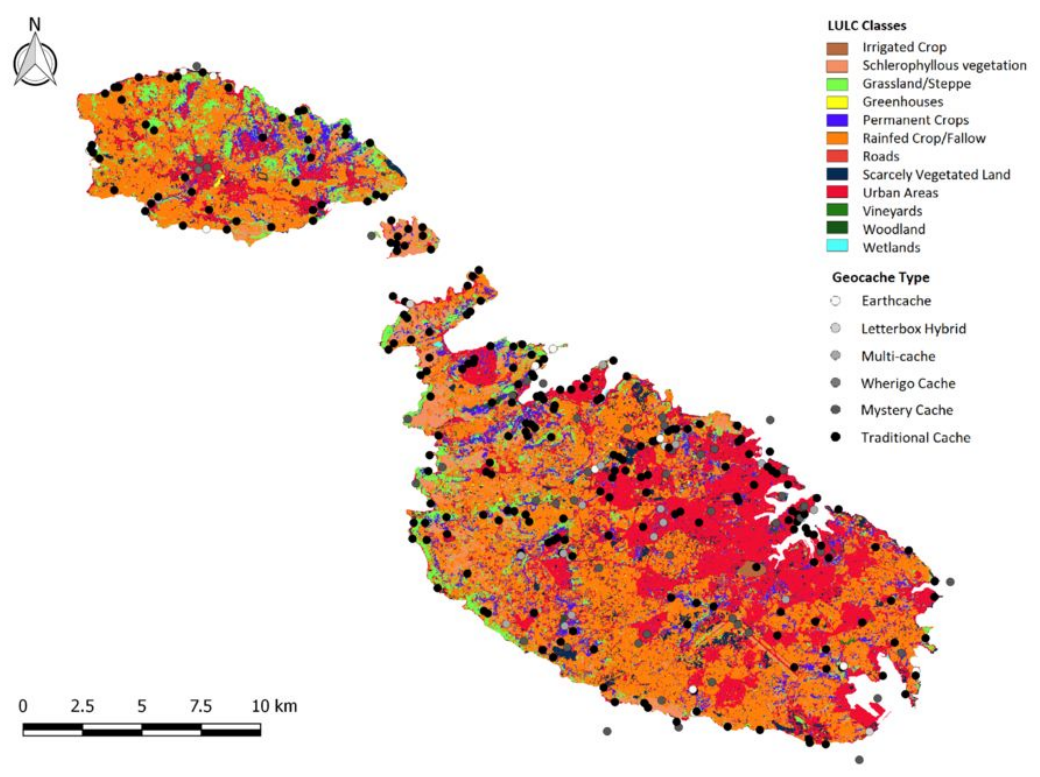

Figure 1.

A land use land cover (LULC) map of the Maltese Islands study area and the location of the investigated geocaches according to the cache type. 


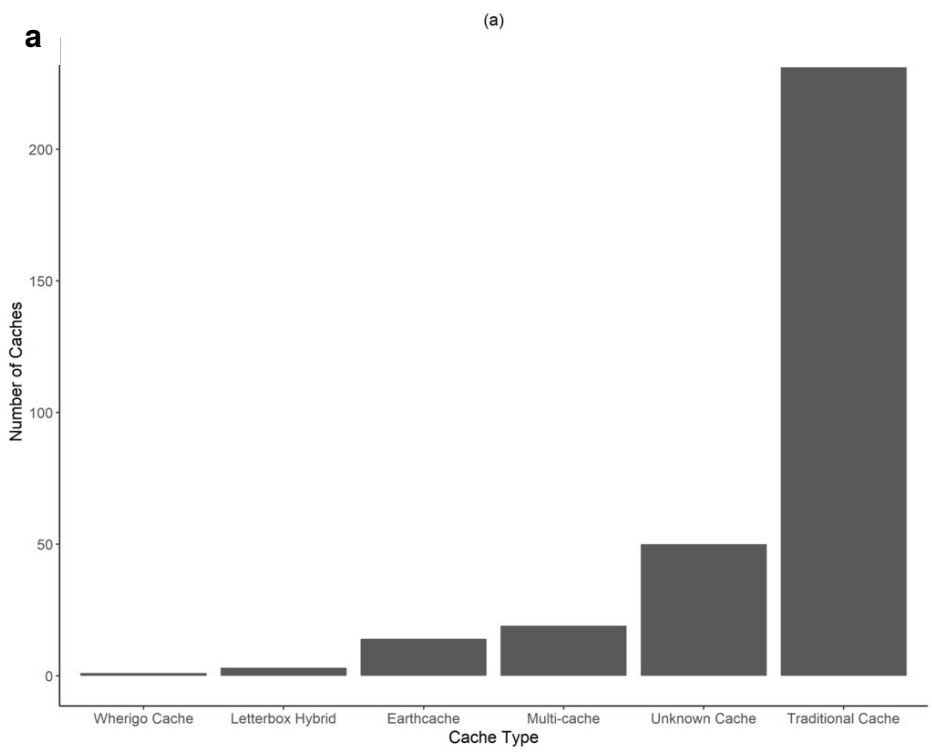

b

(b)

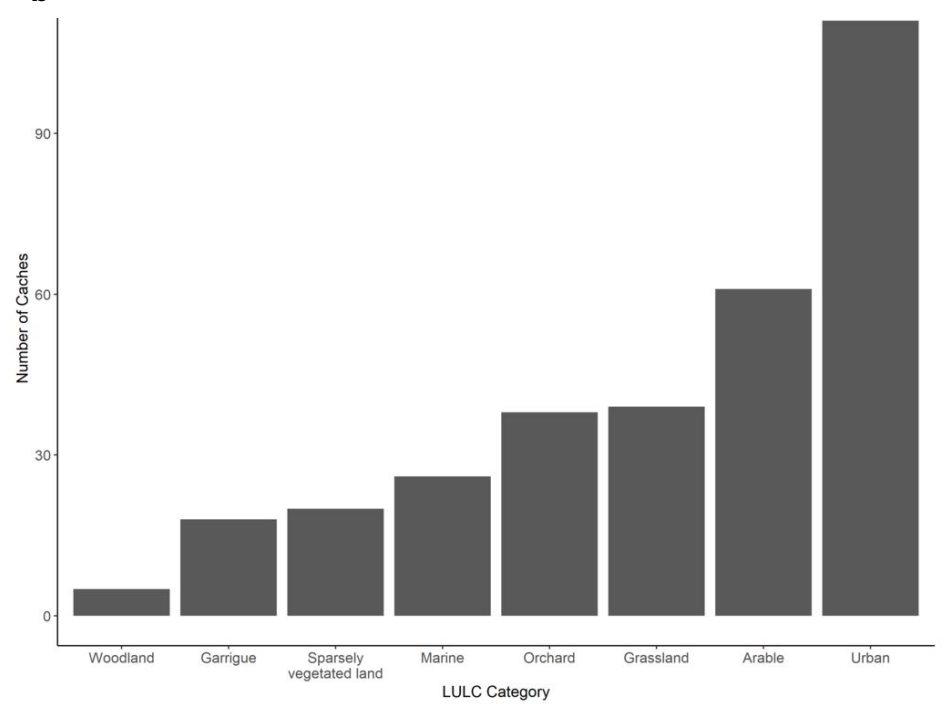

Figure 2.

Number of geocaches according to the (a) cache type and (b) land use land cover (LULC) category.

a: Number of geocaches according to the cache type.

b: Number of geocaches according to the land use land cover (LULC) category. 
a

(a)

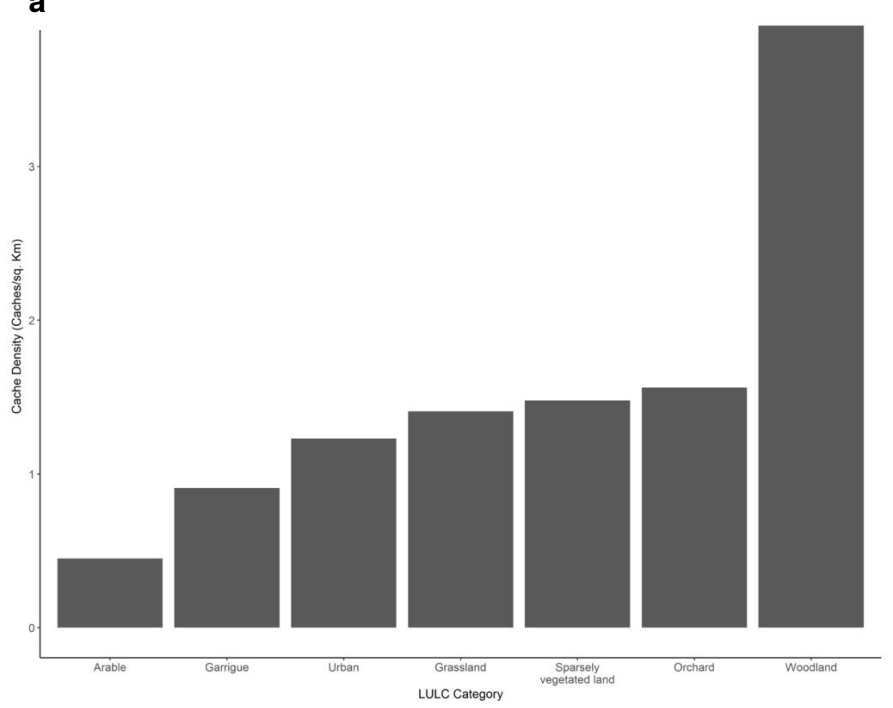

b

(b)

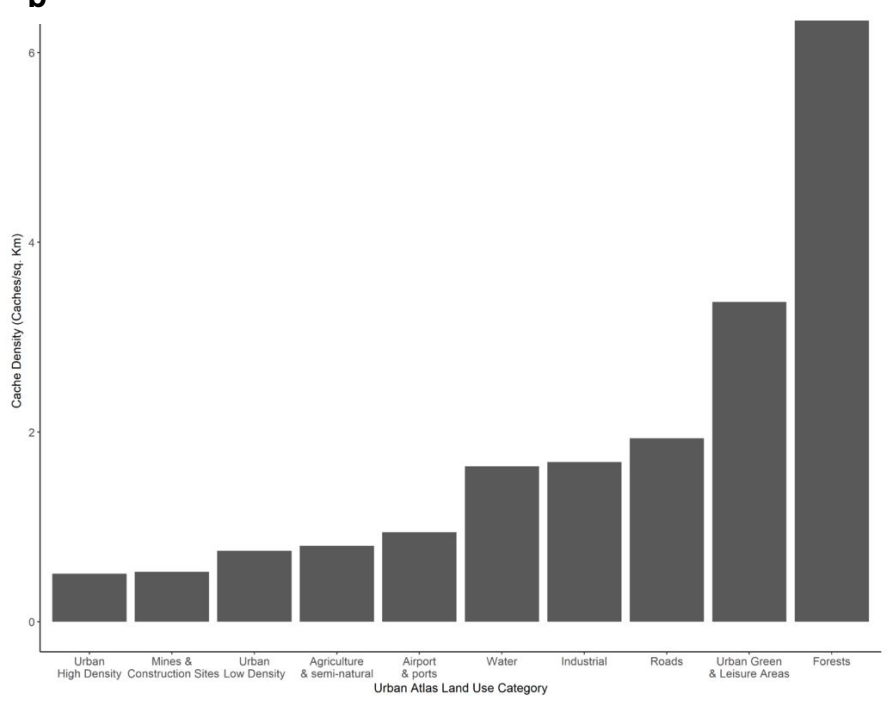

Figure 3.

Relationship between cache density and the land use and land cover when using (a) a land use land cover (LULC) map generated using Sentinel 2 satellite images and (b) the EEA urban atlas land uses for the study area.

a: Relationship between cache density and the land use and land cover when using the land use land cover (LULC) map generated using Sentinel 2 satellite images

b: Relationship between cache density and the land use and land cover when using the EEA urban atlas land uses for the study area. 

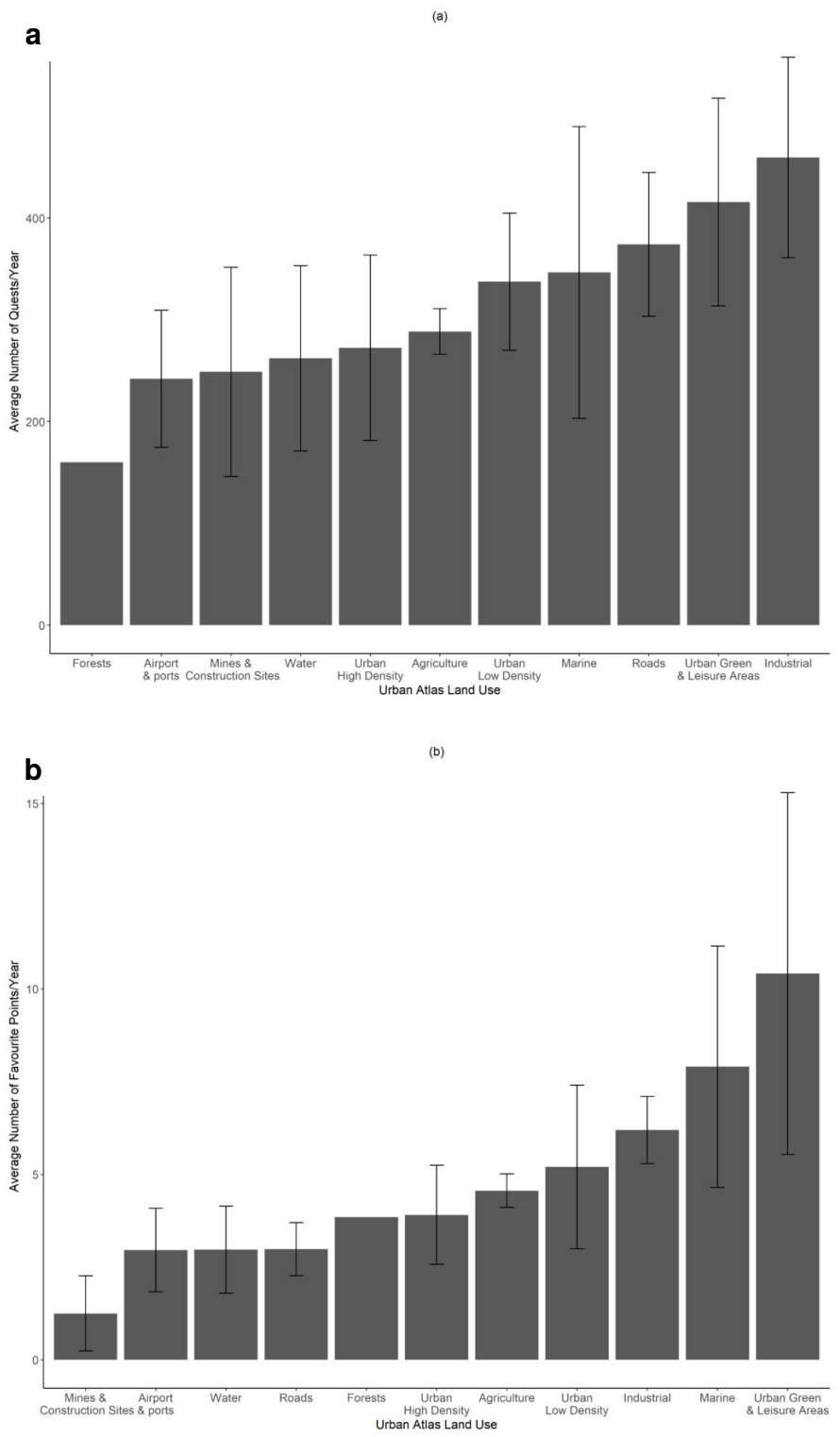

Figure 4.

Mean number of (a) quests and (b) favourite points ( \pm standard error of the mean) for the reclassified Urban Atlas land use categories

a: Mean number of quests ( \pm standard error of the mean) for the reclassified Urban Atlas land use categories

b: Mean number of favourite points ( \pm standard error of the mean) for the reclassified Urban Atlas land use categories 
In order to assess the contribution of gene pool protection ecosystem services in geocaching activities, the influence of sites designation as protected areas on recreational ecosystem services was analysed. Nationally designated areas had a higher geocache density $\left(2.3\right.$ caches $\left./ \mathrm{km}^{2}\right)$ in comparison to sites that did not have any designation $(0.4$ caches $/ \mathrm{km}^{2}$ ). Most of the caches found in designated areas were located in areas of high landscape value and in Special Areas of Conservation and Special Protection Areas (Table 3-1, Appendix 3, Suppl. material 1). The influence of protected area cover on geocache quests and favourite points was assessed using GLMM. No significant difference was recorded for quests and favourite point data between areas designated as protected areas and those which do not have any designation. Similarly, we analysed the association between the number of geocache quests and favourite points and areas protected for their landscape value. Results indicate a higher number of quests and favourite points in area protected for their landscape value, but only favourite points data was significantly positively associated with these landscapes $\left(x^{2}=7.84, p=0.005\right.$ for favourite points; $x^{2}=3.4$ and $p=0.065$ for geocache quests data; the difference in deviance of the two compared models following backward elimination and its significance using a $x^{2}$ test are shown).

Most caches were located in proximity to residential areas and the road network but distance from public transport network and the coast appears to follow a normal distribution (Appendix 3, Suppl. material 1). The number of quests and favourite points were significantly negatively associated with increasing distance from the national road and public transport networks, indicating that accessibility of the geocache location may be an important factor in determining the preference for the geocache (Table 4). Similarly, the number of quests and favourite points were negatively associated with increasing distance from the coastal environment, which, in previous studies, has been shown to be positively associated with experiential use of ecosystems and the aesthetic value of the natural environment (Balzan et al. 2018). The number of geocache favourite points was positively associated with increasing distance from residential areas, indicating a higher number of favourite points in areas located less closely to these zones.

Table 4.

Measuring the relationship between the distance from residential areas, the road and public transport network and coast and the number of quests and favourite points. The difference in deviance between two compared models following backward elimination and its significance using a $X^{2}$ test are shown.

\begin{tabular}{|c|c|c|c|c|c|c|c|c|}
\hline \multirow[t]{2}{*}{ Spatial data } & \multirow[t]{2}{*}{ df } & \multirow{2}{*}{$\begin{array}{l}\text { Mean distance in metres } \\
( \pm \text { SE })\end{array}$} & \multicolumn{3}{|c|}{ Number of Quests } & \multicolumn{3}{|c|}{ Number of Favourite Points } \\
\hline & & & $x^{2}$ & $p$ & Effect & $x^{2}$ & $\mathrm{P}$ & Effect \\
\hline $\begin{array}{l}\text { Distance to Residential } \\
\text { areas }\left(D_{\mathrm{Re}}\right)\end{array}$ & 1 & $1118.35( \pm 51.52)$ & 0.22 & 0.64 & & 5.06 & 0.02 & + \\
\hline Distance to road $\left(\mathrm{D}_{\mathrm{Ro}}\right)$ & 1 & $126.99( \pm 8.23)$ & 17.62 & $<0.0001$ & - & 3.98 & 0.046 & - \\
\hline Distance to bus route $\left(D_{B}\right)$ & 1 & $5155.02( \pm 120.14)$ & 50.7 & $<0.0001$ & - & 9.2 & 0.002 & - \\
\hline Distance to coast $\left(D_{c}\right)$ & 1 & $\begin{array}{l}3843.47 \\
( \pm 82.78)\end{array}$ & 7.4 & 0.007 & - & 8.38 & 0.004 & - \\
\hline
\end{tabular}




\begin{tabular}{|l|l|l|l|l|l|}
\hline$D_{R e} \times D_{B}$ & 1 & 11.76 & 0.0006 & 0.04 & 0.84 \\
\hline$D_{R e} \times D_{R o}$ & 1 & 0.32 & 0.57 & 0.5 & 0.48 \\
\hline$D_{R e} \times D_{C}$ & 1 & 0.86 & 0.35 & 0.20 & 0.65 \\
\hline$D_{C} \times D_{B}$ & 1 & 0.70 & 0.40 & 0.22 & 0.64 \\
\hline$D_{R o} \times D_{C}$ & 1 & 0.00 & 1.00 & 0.62 & 0.43 \\
\hline$D_{R o} \times D_{B}$ & 1 & 3.9 & 0.048 & 0.80 & 0.37 \\
\hline$D_{R o} \times D_{R e} \times D_{B}$ & 1 & 2.48 & 0.12 & 0.48 & 0.48 \\
\hline$D_{R o} \times D_{R e} \times D_{C}$ & 1 & 0.90 & 0.34 & 0.02 & 0.89 \\
\hline$D_{C} \times D_{R e} \times D_{B}$ & 1 & 2.46 & 0.12 & 1.70 & 0.19 \\
\hline$D_{R o} \times D_{C} \times D_{B}$ & 1 & 0.94 & 0.33 & 0.32 & 0.57 \\
\hline$D_{R o} \times D_{R e} \times D_{B} \times D_{C}$ & 1 & 1.06 & 0.30 & 0.00 & 1.00 \\
\hline
\end{tabular}

\section{Understanding geocacher motivations determining ecosystem service flow}

\section{Geocache hunter questionnaires}

A total of 21 responses were obtained for the questionnaire for geocache hunters. Most of the respondents were in the 16 to 29 and 30 to 45 age groups $(n=19)$ and the majority had a tertiary level (10) of education (Appendix 4, Suppl. material 1). The respondent had on average logged $250( \pm 295.3)$ geocaches. Most considered themselves as active geocachers (18) and geocached once or twice per month (8), once per week (6) or less often (5), while 1 respondent geocaches several times a week and another geocached more frequently during spring and autumn. The majority normally chose traditional geocaches (16) over multicaches (3) and mystery caches (2). Most carry out geocaching with others (16) or both alone and the company of others (2) as opposed to alone (3). Car transport to the selected geocache was the most common (12), followed by walking (8) and walking and car transport combined (1). The majority of the respondents had logged most geocaches in woodland areas and in urban built and green areas, whilst the coast and associated beaches and shore also represented a popular environment for geocaching activities (Fig. 5a). Geocaches that enable the geocache hunter to experience nature were favoured (Fig. 5b) and the cache environment was the most important consideration when choosing to log a geocache (Fig. 5c), whilst most enjoyed geocaching as time to solve puzzles and riddles and spent time with family and discovering new and interesting places (Fig. 5d). The geocache hunting experience was ranked positively, with a score of $8.77 \pm$ 1.26 (out of a maximum of 10) and most would visit the same geocaches again (18) by walking or trekking (13), spending time with relatives (7) and to carry out other recreational activities (e.g. walking, picnic and swimming; $n=1$ ). 


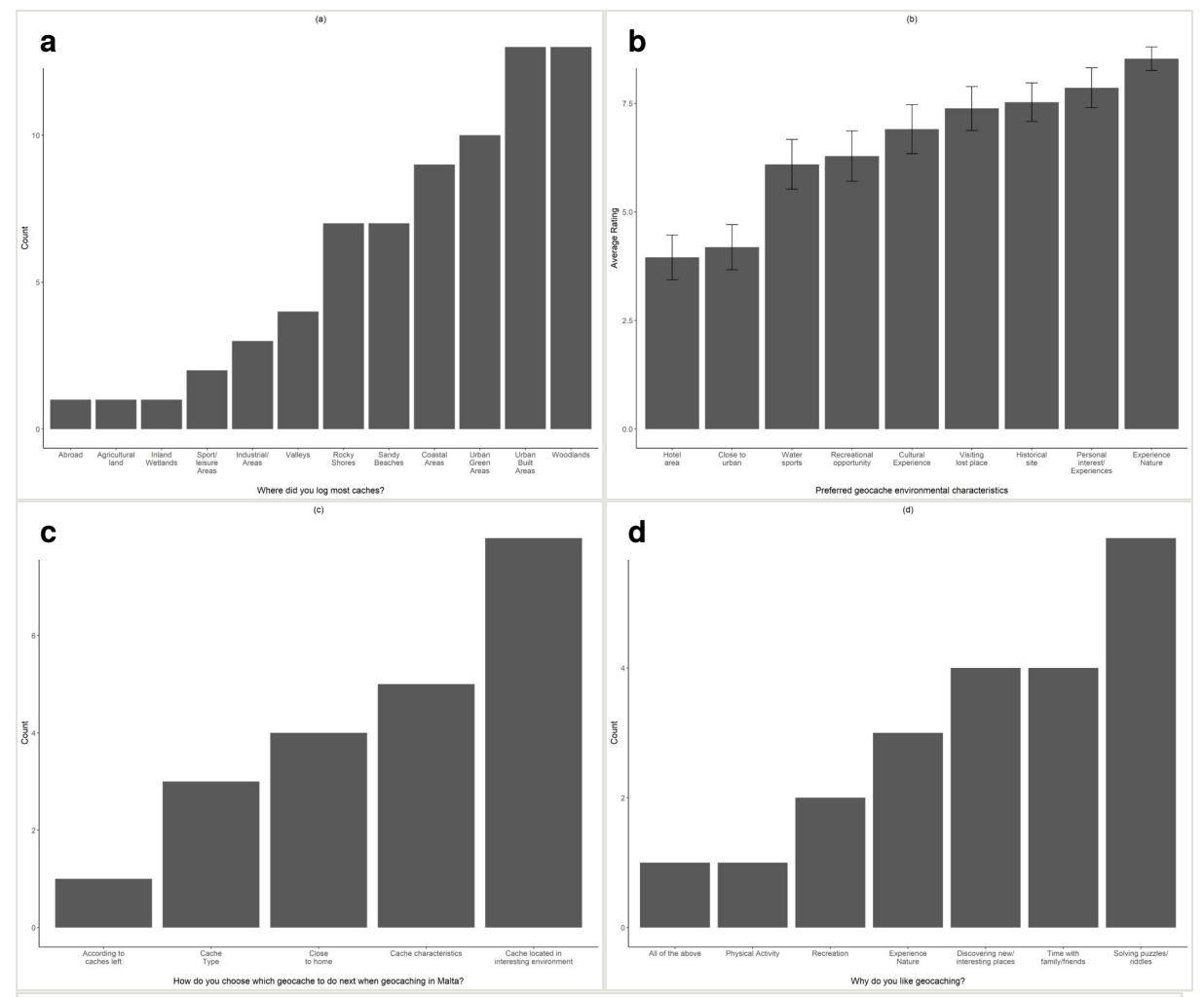

Figure 5.

Geocache hunter questionnaire responses according to the (a) environment where they have logged most geocaches, (b) preferred geocache environmental characteristics, (c) reason why they enjoy geocaching and (d) the main factor considered when choosing a geocache.

a: Geocache hunter questionnaire responses according to the environment where they have logged most geocaches.

b: Geocache hunter questionnaire responses according to the preferred geocache environmental characteristics.

c: Geocache hunter questionnaire responses according to the reason for enjoying geocaching.

d: Geocache hunter questionnaire responses according to the main factor considered when geocaching.

\section{Geocache placer questionnaires}

A total of 39 responses were obtained for the geocache placer questionnaires. Most had a tertiary level of education ( $n=36$, Appendix 5, Suppl. material 1 ). The main reason for placing the geocache in the particular location was because they felt the place was underappreciated (25) or close to the residence or work location of the geocache placer (9). In most cases, the geocache was placed in locations of personal interest to the geocache placer but urban green areas and sites of historical and cultural value were also commonly associated with the owned geocaches (Fig. 6a). Most of the respondents placed their 
geocaches in woodland, urban or coastal areas and in urban green spaces (Fig. 6b), but built up and coastal areas and green spaces were ranked higher in terms of their potential to provide a positive recreational experience to the geocache finder (Fig. 6c).

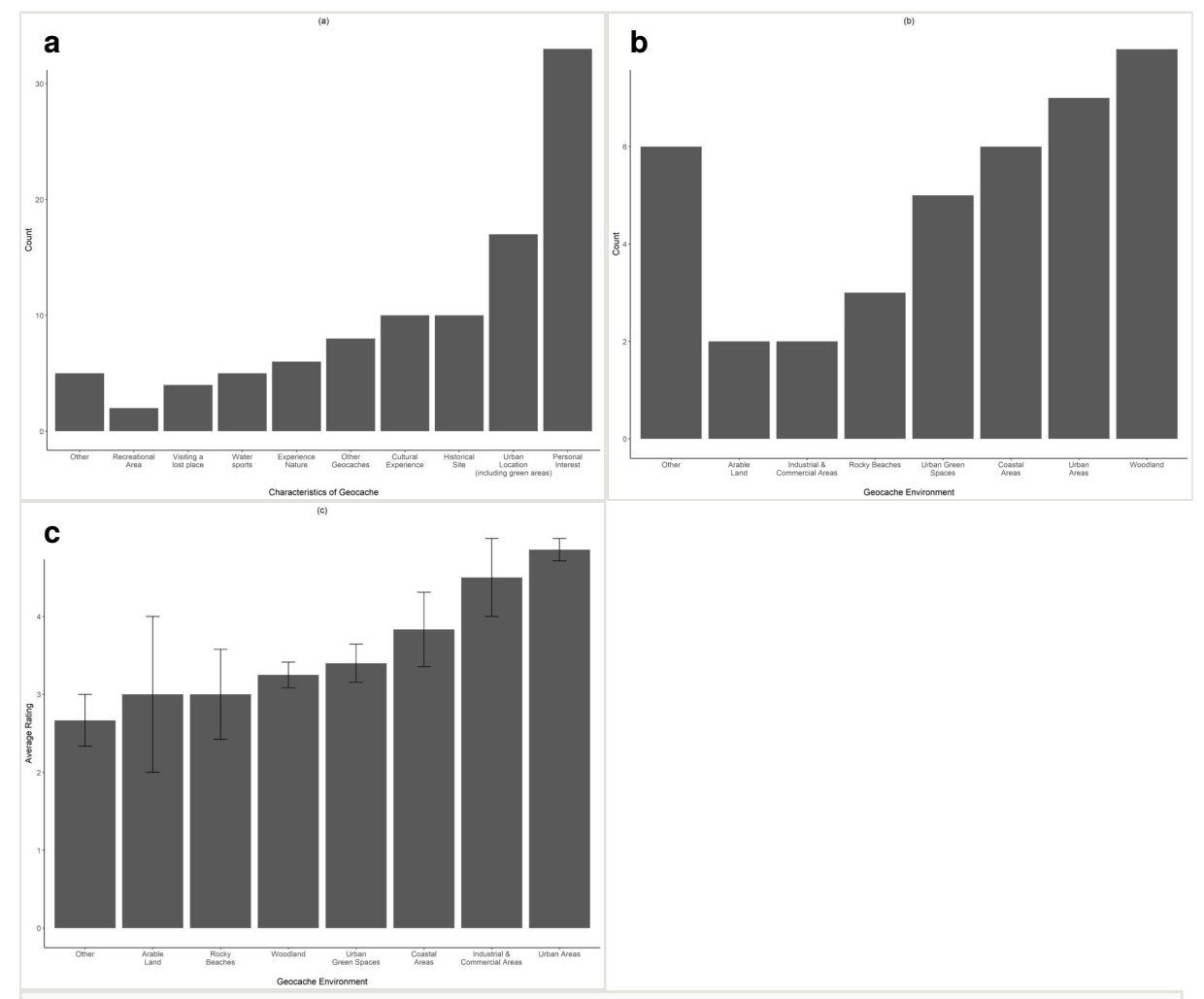

Figure 6.

Figure 6 - Geocache placer questionnaire responses according to the (a) characteristics of the geocache, (b) the environment where the geocache was placed and (c) the average rating for the experience assigned to the geocache by the placer.

a: Geocache placer questionnaire responses according to the characteristics of the geocache.

b: Geocache placer questionnaire responses according to the environment where the geocache was placed.

c: Geocache placer questionnaire responses according to the average rating for the experience assigned to the geocache by the placer.

\section{Discussion}

\section{Spatial variation in ecosystem services capacity and flow}

The analysis of geocaching data demonstrates that most geocaches were located in, or in close proximity to, urban land cover. However, the highest geocache density was not 
recorded in the urban land cover but in semi-natural categories and in urban green and sports and leisure areas, indicating that these environments have a higher capacity to deliver recreational ecosystem services to urban communities, as measured through the use of geocaching data. Accessibility to semi-natural and urban green areas appears to be a particularly important characteristic influencing the capacity of recreational ecosystem services and most of the geocaches were located in close proximity to residential areas and the road network. Similarly, recreational ecosystem services flow data also appear to be strongly linked to the accessibility of the environment. This was also confirmed from questionnaire data for geocache placers, where proximity to work or residence areas was considered as being important for the respondents and these also explained that their geocaches were placed in sites considered as being of personal interest or in urban green areas.

Results presented here are supported by those in Cord et al. (2015), whose study found the highest total number of geocaches and highest geocache density in urban green spaces. Similarly, in a study carried out in the United Kingdom, sub-urban and urban sites were associated with higher recreation potential compared to rural sites (Radford and James 2013) while, in another study in Barcelona, urban areas had the lowest recreational ecosystem services capacity but the highest recreation flow was recorded in forest areas surrounding urban settlements (Baró et al. 2016). Accessibility was also a key consideration when mapping the outdoor recreational ecosystem service potential (Paracchini et al. 2014) and was also identified as one of the most important characteristics of recreational sites in another study carried out in Finland (Yli-Pelkonen 2013).

Similar to other studies investigating recreational ecosystem services (Yli-Pelkonen 2013), geocaching was seen by geocache hunters as an opportunity to experience nature, spend time with family and friends and getting physical exercise. Caches located in urban areas, as well as in urban green and sports and leisure areas, had the highest number of quests and urban green and sports and leisure areas were also characterised with the highest favourite rating, demonstrating a preference for these caches. Proximity to the coastal environment and landscapes of higher conservation value were also associated with a higher number of quests and favourite points, whilst increasing distance from residential areas was associated with a higher number of favourite points. These results were also supported by those obtained from the questionnaires with geocache hunters, as geocaches that enable a 'nature experience' were also favoured by geocache hunters. These identified woodland, urban green areas, the coast and beaches as the environments in which they log most caches, whilst most of the geocache placers participating in the questionnaire in this study placed their geocaches in woodland, urban or coastal areas and in urban green spaces. These ranked coastal areas and urban built and green spaces higher in terms of their potential to provide a positive recreational experience to the geocache hunter. Similar results have been obtained by previous studies investigating the motivations of geocachers (Cord et al. 2015, Telaar et al. 2014), while other studies have similarly shown that the coastal environment is associated with increased recreational ecosystem services flow (Balzan et al. 2018, Paracchini et al. 2014). 
This study contrasts with previous observations from the study area highlighting the importance of semi-natural habitats for aesthetic (cultural) ecosystem services (Balzan et al. 2018). Similar results were also obtained by Radford and James (2013), who, in their study, found a lower aesthetic value of highly urbanised environment. In the study by Balzan et al. (2018), aesthetic ecosystem services were associated with areas having a higher number of habitats of conservation interest from the study area. In contrast, within this study, designated protected areas were not significantly associated with increased flow of recreational ecosystem services, demonstrating that there are different factors affecting cultural ecosystem service capacity and flow (Radford and James 2013) and indicating the importance of identifying suitable indicators that directly reflect the different types of cultural ecosystem services and associated benefits, in the implementation of ecosystem service assessment and mapping activities.

The strong positive association of recreational ecosystem services with landscape value demonstrates that processes which essentially degrade the landscape are also likely to have a negative impact on the capacity and flow of this service. This is particularly important in the context of strong urbanisation and tourism development trends within the study area and, in general, within the Mediterranean region, leading to intense pressure on ecosystems as a consequence of land use change. This is exacerbated within the study area as a consequence of the limited land resources available within an insular Mediterranean environment, in particular as traditional management practices decline and are replaced by more intensified management associated with strong tourism and industrial development (Aretano et al. 2013, Petrosillo et al. 2013, Tzanopoulos and Vogiatzakis 2011).

\section{Evidence-based management of urban recreational ecosystem services}

Results obtained here demonstrate that the development of an understanding of the spatial variation in availability of green infrastructure and of ecosystem service capacity and flows is critical in order to implement the ecosystem service concept for the development of policies that promote the sustainable use of ecosystem services (Schröter et al. 2014). Urban areas do not necessarily provide fewer ecosystem services compared to other regions, as urban green infrastructure, such as tree cover or peri-urban agriculture, can significantly contribute to support biodiversity and ecosystem service delivery (Dennis and James 2016, Larondelle and Haase 2013). However, in this case, the high recreational ecosystem service flow in green urban areas appears to be unbalanced with the capacity of these spaces to deliver these services given the relatively low number of caches in these environments. This imbalance between capacity and flow would be expected to be higher in areas with higher population density and lower availability of urban green infrastructure (Balzan 2017, Tratalos et al. 2007). Similarly, in a recent study measuring accessibility of green urban areas, several Southern European cities had below-average availability and accessibility of green urban areas to the city inhabitants (Kabisch et al. 2016). These observations demonstrate the need to develop our understanding of composition and spatial configuration of landscapes, especially in terms of the availability of green spaces and the delivery of ecosystem services contributing to human well-being and the 
importance of policies and urban planning practices that maintains and improves the availability of green infrastructure.

To provide guidance in the choice of appropriate ecosystem service assessment and mapping methods, tiered approaches have been proposed, with tier 1 approaches being dependent on readily available data, tier 2 includes more specific information from the study area whilst tier 3 approaches are more data intensive and are based on an improved understanding of the underpinning processes (Grêt-Regamey et al. 2015, Gret-Regamey et al. 2017). This study has used different types of data to assess recreational ecosystem services and demonstrates that practitioners can use such an approach to develop a more detailed understanding of the links between recreational ecosystem services and the socioecological conditions and to predict areas with higher (or lower) urban recreational ecosystem service capacity and flow, which is necessary for the preparation of ecosystem services maps. Such approaches move away from traditional proxy-based (tier 1) approaches that are based on more easily available land cover data, which are common in the assessment of cultural ecosystem services (Fagerholm and Palomo 2017) and are often constrained by the availability of data. An improved understanding of the relationship between the components of the ecosystem service delivery chain and their relationship with socio-ecological factors, permits the development of more precise process-based (tier 3) ecosystem service assessments and mapping approaches (Grêt-Regamey et al. 2015, Lavorel et al. 2017). These are considered as being more useful in providing answers to urban planners and for the evaluation of management measures (Grêt-Regamey et al. 2015, Gret-Regamey et al. 2017).

\section{Conclusions}

This study has used spatial geocaching data in order to assess the capacity and flow of urban recreational services, whilst also using data generated from questionnaires with geocachers to develop an understanding of the motivations that are likely to influence ecosystem service flows. Geocaching was seen as an opportunity to experience nature, spend time with family and friends and to get physical exercise. Results from the analysis of geocache spatial data indicate that most caches are located in urban land use categories, with the highest cache densities being recorded in green urban areas and semi-natural ecosystems. Ecosystem service flow was positively associated with accessibility of the geocache, areas of high landscape value and proximity to the coastal environment. These results are discussed in further detail as they provide evidence of the importance of developing spatial indicators that rely on an improved understanding of the quantitative and qualitative relationships between ecosystems and ecosystem service capacity and flow, leading to human well-being. Finally, these results provide evidence of relevance for landscape and urban planning which promotes the availability of green infrastructure in urban areas for their important contribution of these to human well-being. 


\section{Acknowledgements}

Georeferenced data on the geocaches were kindly provided by Groundspeak, Inc. (owner of the largest geocaching site: http://www.geocaching.com). MVB has received funding from the European Union's Horizon 2020 research and innovation programme under grant agreement No 642007 for the "ESMERALDA - Enhancing ecosystem services mapping for policy and decision making" project (http://esmeralda-project.eu/) and also acknowledges research support within the framework of the "EnRoute - Enhancing Resilience Of Urban Ecosystems through Green Infrastructure" project of the European Commission in the framework of the EU Biodiversity Strategy and the Green Infrastructure Strategy to produce this research.

\section{References}

- $\quad$ Aretano R, Petrosillo I, Zaccarelli N, Semeraro T, Zurlini G (2013) People perception of landscape change effects on ecosystem services in small Mediterranean islands: $A$ combination of subjective and objective assessments. Landsc. Urban Plan 112: 63-73. https://doi.org/10.1016/j.landurbplan.2012.12.010

- Balzan M, Caruana J, Zammit A (2018) Assessing the capacity and flow of ecosystem services in multifunctional landscapes : evidence of a rural-urban gradient in a Mediterranean small island state. Land Use Policy 75: 711-725. https://doi.org/10.1016/ j.landusepol.2017.08.025

- $\quad$ Balzan MV (2017) Ecology for the city : analysing the role of green infrastructure in creating liveable cities. The Fourth Valletta 2018 Annual International Conference Living Cities, Liveable Spaces: Placemaking \& Identity. Valletta 2018: European Capital of Culture. Valletta, Malta.

- $\quad$ Baró F, Palomo I, Zulian G, Vizcaino P, Haase D, Gómez-Baggethun E (2016) Mapping ecosystem service capacity, flow and demand for landscape and urban planning: A case study in the Barcelona metropolitan region. Land use policy 57: 405-417. https:// doi.org/10.1016/j.landusepol.2016.06.006

- $\quad$ Bastian O, Syrbe R-, Rosenberg M, Rahe D, Grunewald K (2013) The five pillar EPPS framework for quantifying, mapping and managing ecosystem services. Ecosyst. Serv 4: 15-24. https://doi.org/10.1016/i.ecoser.2013.04.003

- $\quad$ Cord AF, Roeßiger F, Schwarz N (2015) Geocaching data as an indicator for recreational ecosystem services in urban areas: Exploring spatial gradients, preferences and motivations. Landsc. Urban Plan 144: 151-162. https://doi.org/10.1016/ j.landurbplan.2015.08.015

- Daniel TC, Muhar A, Arnberger A, Aznar O, Boyd JW, Chan KM, Costanza R, Elmqvist T, Flint CG, Gobster PH, Gret-Regamey A, Lave R, Muhar S, Penker M, Ribe RG, Schauppenlehner T, Sikor T, Soloviy I, Spierenburg M, Taczanowska K, Tam J, Dunk A (2012) Contributions of cultural services to the ecosystem services agenda. Proc. Natl. Acad. Sci 109: 8812-8819. https://doi.org/10.1073/pnas.1114773109

- de Groot R, Fisher B, Christie M, Aronson J, Braat L, Haines-Young R, Gowdy J, Maltby E, Neuville A, Polasky S, Portela R, Ring I, Blignaut J, Brondizio E, Costanza R, Jax K, Kadekodi GK, May PH, Shmelev S (2010) Integrating the ecological and economic 
dimensions in biodiversity and ecosystem service valuation. The Economics of Ecosystems and Biodiversity : The Ecological and Economic Foundations.

- de Groot RS, Alkemade R, Braat L, Hein L, Willemen L (2010) Challenges in integrating the concept of ecosystem services and values in landscape planning, management and decision making. Ecol. Complex 7: 260-272. https://doi.org/10.1016/ j.ecocom.2009.10.006

- Dennis M, James P (2016) Site-specific factors in the production of local urban ecosystem services: A case study of community-managed green space. Ecosyst. Serv 17: 208-216. https://doi.org/10.1016/j.ecoser.2016.01.003

- Drusch M, Del Bello U, Carlier S, Colin O, Fernandez V, Gascon F, Hoersch B, Isola C, Laberinti P, Martimort P, Meygret A, Spoto F, Sy O, Marchese F, Bargellini P (2012) Sentinel- 2: ESA's Optical High-Resolution Mission for GMES Operational Services. Remote Sens. Environ 120: 25-36. https://doi.org/10.1016/j.rse.2011.11.026

- Fagerholm N, Palomo I (2017) Participatory GIS approaches for mapping ecosystem services, in: Mapping Ecosystem Services. Pensoft Publishers, Sofia.

- $\quad$ Figueroa-Alfaro RW, Tang Z (2016) Evaluating the aesthetic value of cultural ecosystem services by mapping geo-tagged photographs from social media data on Panoramio and Flickr. J. Environ. Plan. Manag 568: 1-16. https:// doi.org/10.1080/09640568.2016.1151772

- $\quad$ Fournier DA, Skaug HJ, Ancheta J, lanelli J, Magnusson A, Maunder MN, Nielsen A, Sibert J (2012) AD Model Builder: using automatic differentiation for statistical inference of highly parameterized complex nonlinear models. Optim. Methods Softw https:// doi.org/10.1080/10556788.2011.597854

- $\quad$ Gret-Regamey A, Weibel B, Rabe S, Burkhard B (2017) A tiered approach for ecosystem services mapping. Mapping Ecosystem Services. Pensoft Publishers, Sofia 213-217.

- $\quad$ Grêt-Regamey A, Weibel B, Kienast F, Rabe S-, Zulian G (2015) A tiered approach for mapping ecosystem services. Ecosyst. Serv 13: 16-27. https://doi.org/10.1016/ j.ecoser.2014.10.008

- Haines-Young R, Potschin M (2013) Common International Classification of Ecosystem Services (CICES): Consultation on Version 4, August-December 2012. www.cices.eu. Accessed on: 2017-1-03.

- Hausmann A, Toivonen T, Slotow R, Tenkanen H, Moilanen A, Heikinheimo V, Di Minin E (2017) Social Media Data Can. Conserv. Lett 1-10. https://doi.org/10.1111/conl.12343

- Kabisch N, Strohbach M, Haase D, Kronenberg J (2016) Urban green space availability in European cities. Ecol. Indic 70: 586-596. https://doi.org/10.1016/

j.ecolind.2016.02.029

- Koniak G, Sheffer E, Noy-Meir I (2012) Recreation as an ecosystem service in open landscapes in the Mediterranean region in Israel: Public preferences. Isr. J. Ecol. Evol 57: 151-171. https://doi.org/10.1560/IJEE.57.1-2.151

- Larondelle N, Haase D (2013) Urban ecosystem services assessment along a ruralurban gradient: A cross-analysis of European cities. Ecol. Indic 29: 179-190. https:// doi.org/10.1016/i.ecolind.2012.12.022

- Lavorel S, Bayer A, Bondeau A, Lautenbach S, Ruiz-Frau A, Schulp N, Seppelt R, Verburg P, Teeffelen Av, Vannier C, Arneth A, Cramer W, Marba N (2017) Pathways to bridge the biophysical realism gap in ecosystem services mapping approaches. Ecol. Indic 74: 241-260. https://doi.org/10.1016/j.ecolind.2016.11.015 
- M.A. (2005) Ecosystems and Human Well-Being: A Framework for Assessment. Island Press, London.

- Maes J, Paracchini MM, Zulian G, Dunbar MB, Alkemade R (2012) Synergies and trade-offs between ecosystem service supply, biodiversity, and habitat conservation status in Europe. Biol. Conserv 155: 1-12. https://doi.org/10.1016/j.biocon.2012.06.016

- Maes J, Liquete C, Teller A, Erhard M, Paracchini ML, Barredo JI, Grizzetti B, Cardoso A, Somma F, Petersen JE, Meiner A, Gelabert ER, Zal N, Kristensen P, Bastrup-Birk A, Biala K, Piroddi C, Egoh B, Degeorges P, Fiorina C, Santos-Mart??n F, Naru??evi??ius V, Verboven J, Pereira HM, Bengtsson J, Gocheva K, Marta-Pedroso C, Sn??II T, Estreguil C, San-Miguel-Ayanz J, Perez-Soba M, Gret-Regamey A, Lilleb?? Al, Malak DA, Cond?? S, Moen J, Czucz B, Drakou EG, Zulian G, Lavalle C (2016a) An indicator framework for assessing ecosystem services in support of the EU Biodiversity Strategy to 2020. Ecosyst. Serv 17: 14-23. https://doi.org/10.1016/i.ecoser.2015.10.023

- Maes J, Zulian G, Thijssen M, Castell C, Baró F, Ferreira A, Melo J, Garrett C, David N, Alzetta C, Geneletti D, Cortinovis C, Zwierzchowska I, Louro Alves F, Souto Cruz C, Blasi C, Alós Ortí M, Attorre F, Azzella M, Capotorti G, Copiz R, L F, Manes F, Marando F, Marchetti M, Mollo B, Salvatori E, Zavattero L, Zingari P, Giarratano M, Bianchi E, Dupre E, Barton D, Stange E, Perez-Soba M, Eupen M, Verweij P, Vries A, Kruse H, Polce C, Cugny-Seguin M, Erhard M, Nicolau R, Fonseca A, Fritz M, Teller A (2016b) Mapping and Assessment of Ecosystems and their Services. Urban Ecosystems. Publications Office of the European. Mapping and Assessment of Ecosystems and their Services. Urban Ecosystems. Publications Office of the European https:// doi.org/10.2779/75203

- $\quad$ M.E.P.A. (2010) The Environment Report 2008 Sub-Report 4 Land. The Environment Report 2008. Malta Environment \& Planning Authority, Malta.

- $\quad$ Müller F, Burkhard B (2012) The indicator side of ecosystem services. Ecosyst. Serv 1: 26-30. https://doi.org/10.1016/i.ecoser.2012.06.001

- $\quad$ Neustaedter C, Tang A, Judge T (2010) The Role of Community and Groupware in Geocache Creation and Maintenance. Proceedings of the SIGCHI Conference on Human Factors in Computing Systems. Georgia, Atlanta. Atlanta, Georgia, USA

- $\quad$ N.S.O. (2014) Malta in Figures 2014. National Statistics Office, Valletta, Malta.

- $\quad$ N.S.O. (2017) Regional Statistics Malta. National Statistics Office, Malta.

- O'Farrell PJ, Anderson PM (2010) Sustainable multifunctional landscapes: a review to implementation. Current Opinion in Environmental Sustainability 2: 59-65. https:// doi.org/10.1016/j.cosust.2010.02.005

- Paracchini ML, Zulian G, Kopperoinen L, Maes J, Schägner JP, Termansen M, Zandersen M, Perez-Soba M, Scholefield P, Bidoglio G (2014) Mapping cultural ecosystem services: A framework to assess the potential for outdoor recreation across the EU. Ecological Indicators 45: 371-385. https://doi.org/10.1016/i.ecolind.2014.04.018

- Patton M (1996) ISLANDS IN TIME. Routledge, London. https:// doi.org/10.4324/9780203433331

- Petrosillo I, Costanza R, Aretano R, Zaccarelli N, Zurlini G (2013) The use of subjective indicators to assess how natural and social capital support residents' quality of life in a small volcanic island. Ecological Indicators 24: 609-620. https://doi.org/10.1016/ j.ecolind.2012.08.021

- Potschin M, Haines-Young R (2011) Ecosystem services. Progress in Physical Geography 35 (5): 575-594. https://doi.org/10.1177/0309133311423172 
- $\quad$ QGIS Development Team (2016) QGIS Geographic Information System.

- Radford KG, James P (2013) Changes in the value of ecosystem services along a rural-urban gradient: A case study of Greater Manchester, UK. Landscape and Urban Planning 109 (1): 117-127. https://doi.org/10.1016/j.landurbplan.2012.10.007

- R Development Team (2016) R: A Language and Environment for Statistical Computing. R Foundation for Statistical Computing. Vienna.

- Richards DR, Friess DA (2015) A rapid indicator of cultural ecosystem service usage at a fine spatial scale: Content analysis of social media photographs. Ecol. Indic 53:

187-195. https://doi.org/10.1016/j.ecolind.2015.01.034

- $\quad$ Schembri PJ (1997) The Maltese Islands: climate, vegetation and landscape. GeoJournal 41: 1-11. https://doi.org/10.1023/A:1006828706452

- $\quad$ Schröter M, Barton D, Remme R, Hein L (2014) Accounting for capacity and flow of ecosystem services: A conceptual model and a case study for Telemark, Norway. Ecological Indicators 36: 539-551. https://doi.org/10.1016/j.ecolind.2013.09.018

- Selman P (2009) Planning for landscape multifunctionality. Sustain. Sci. Pract. Policy 5: 45-52.

- $\quad$ Skaug H, Fournier D, Nielsen A, Magnusson A, Bolker B (2013) Generalized Linear Mixed Models using AD Model Builder. R package version 0.7.3.

- Telaar D, Krüger A, Schöning J (2014) A Large-Scale Quantitative Survey of the German Geocaching Community in 2007. Adv. Human-Computer Interact 275815.

- Tenkanen H, Minin ED, Heikinheimo V, Hausmann A, Herbst M, Kajala L, Toivonen T (2017) Instagram, Flickr, or Twitter: Assessing the usability of social media data for visitor monitoring in protected areas. Scientific Reports 7 (1): . https://doi.org/10.1038/ s41598-017-18007-4

- $\quad$ Tratalos J, Fuller R, Warren P, Davies R, Gaston K (2007) Urban form, biodiversity potential and ecosystem services. Landscape and Urban Planning 83 (4): 308-317. https://doi.org/10.1016/i.landurbplan.2007.05.003

- Tzanopoulos J, Vogiatzakis I (2011) Processes and patterns of landscape change on a small Aegean island: The case of Sifnos, Greece. Landscape and Urban Planning 99 (1): 58-64. https://doi.org/10.1016/..landurbplan.2010.08.014

- Venables WN, Ripley BD (2002) Modern Applied Statistics with S. Statistics and Computing https://doi.org/10.1007/978-0-387-21706-2

- Villamagna A, Angermeier P, Bennett E (2013) Capacity, pressure, demand, and flow: A conceptual framework for analyzing ecosystem service provision and delivery. Ecological Complexity 15: 114-121. https://doi.org/10.1016/j.ecocom.2013.07.004

- Villamagna A, Mogollón B, Angermeier P (2014) A multi-indicator framework for mapping cultural ecosystem services: The case of freshwater recreational fishing. Ecological Indicators 45: 255-265. https://doi.org/10.1016/i.ecolind.2014.04.001

- Weyland F, Laterra P (2014) Recreation potential assessment at large spatial scales: A method based in the ecosystem services approach and landscape metrics. Ecological Indicators 39: 34-43. https://doi.org/10.1016/i.ecolind.2013.11.023

- Yli-Pelkonen V (2013) Importance of recreational ecosystem services in Helsinki, Finland. Management of Environmental Quality: An International Journal 24 (3): 365-382. https://doi.org/10.1108/14777831311322668 


\section{Supplementary material}

\section{Suppl. material 1: Supplementary Information doi}

Authors: Balzan, MV and Debono, I

Data type: Questionnaire scripts, images, descriptive analysis of geocache data

Filename: SI_Debono\&Balzan_One_Ecosystem_paper_rev1.pdf - Download file (1.04 MB)

\section{Endnotes}

*1 https://www.flickr.com/

*2 https://www.instagram.com

*3 https://twitter.com/

*4 https://www.geocaching.com

*5 https://newsroom.geocaching.com/fast-facts/ (Accessed: 19/1/2018)

*6 https://www.facebook.com/groups/385214601501797/ 